\title{
Magmatic-hydrothermal BIF-hosted iron ore in the SE São Francisco craton, Brazil
}

\author{
F. C. Silveira Braga ${ }^{1,2}$ C. A. Rosière ${ }^{2}$ J. O. S. SANTos \\ ${ }^{3}$ A. PACK $^{4}$ S. G. HAGEMANN ${ }^{5}$
}

${ }^{1}$ UEMG, João Monlevade, MG, Brazil, ${ }^{2}$ UFMG, Belo Horizonte, MG, Brazil, ${ }^{3}$ UEA, Manaus, AM, Brazil, ${ }^{4}$ GeorgAugust-Universität, Göttingen, Germany, ${ }^{5}$ UWA, Perth, WA, Australia

Statherian iron formation-bearing sequences of the Lower Espinhaço Supergroup are present in SE São Francisco Craton within the Guanhães Tectonic Block and Southern Espinhaço Belt, Eastern South America. Such sequences have undergone multiphase $\mathrm{Fe}$ mineralization associated with a large hydrothermal system caused by crustal reworking and melting under particularly "hot" orogenic conditions. Massive, irregular shaped hematite-magnetite high-grade $(>60 \%$ wt. Fe) orebodies occur at the contact zone of pegmatite bodies and quartz veins and display a granular fabric, contrasting with the hosting schistose quartz-hematite iron formation (IF). Mineralization of the IF developed during at least three distinct stages of the Brasilian orogeny: (1) syn-collisional stage (580-560 Ma) along shear zones, associated with the transposition of layers and oriented platy low trace element bearing hematite crystals; (2) late- to postcollisional phase $(560 \sim 530 \mathrm{Ma})$ with the formation of massive magnetite bodies developed during contact metamorphic-metasomatism with an anatectic pegmatite intrusion that segregated from the re-melted Paleoproterozoic Borrachudos granite, and (3) post-tectonic hydrothermal stage characterized by the oxidation of magnetite to kenomagnetite/maghemite and martite and crystallization of granular hematite during gravitational collapse of the orogeny ( $\sim 530-490 \mathrm{Ma})$. Mineral chemistry analyses reveal a similar composition of iron oxides located in the ore and pegmatite. Notably, $\mathrm{Ti}$ and $\mathrm{Mn}$ were mobile during the contactmetasomatic stages, generating Mn-rich kenomagnetite, Tirich hematite, and ilmenite inclusions. The $\delta^{18} \mathrm{O}$ values of iron oxides are relatively high compared with values of iron oxides of other IF-hosted iron ore worldwide. Platy hematite and magnetite from sheared IF have values between 1.7$8.1 \%$. The $\delta^{18} \mathrm{O}$ data of iron oxides from pegmatite and quartz veins fall in a similar range between $1.8-5.0 \%$. The lowest $\delta^{18} \mathrm{O}$ values relate to late-stage hematite (-1.6-2.6\%) and martite-kenomagnetite from iron high-grade ore (-1.5$0.7 \%$ ). The high $\delta^{18} \mathrm{O}$ values are interpreted to be the result of magmatic hydrothermal fluids that circulated during the upgrade of IF to iron ore. 